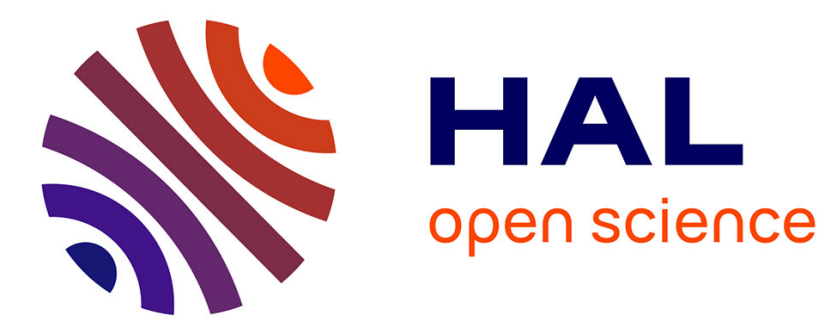

\title{
The Natural World
}

Christine Ferlampin-Acher

\section{To cite this version:}

Christine Ferlampin-Acher. The Natural World. Johnny McFadyen et Leah Tether Handbook of Arthurian Romance: King Arthur's Court in Medieval European Literature, De Gruyter, p. 239-258, 2017, 10.1515/9783110432466-016 . hal-01624024

\section{HAL Id: hal-01624024 \\ https://hal.science/hal-01624024}

Submitted on 26 Oct 2017

HAL is a multi-disciplinary open access archive for the deposit and dissemination of scientific research documents, whether they are published or not. The documents may come from teaching and research institutions in France or abroad, or from public or private research centers.
L'archive ouverte pluridisciplinaire HAL, est destinée au dépôt et à la diffusion de documents scientifiques de niveau recherche, publiés ou non, émanant des établissements d'enseignement et de recherche français ou étrangers, des laboratoires publics ou privés.

\section{(1)(1) $\$(0)$}

Distributed under a Creative Commons Attribution - NonCommercial - ShareAlikel 4.0 


\section{The Natural World}

\section{Christine Ferlampin-Acher}

\section{Rennes 2 CELLAM}

«The Natural World» in Johnny McFadyen et Leah Tether (dir.), Handbook of Arthurian Romance: King Arthur's Court in Medieval European Literature, Berlin/Boston, De Gruyter, 2017, p. 239-258;

The theme of nature in the literature of the Middle Ages is a complex subject. It encompasses both what the modern reader understands by the word nature (animals, plants, countryside, etc.) and its many medieval meanings. In the Middle Ages, it was used as an allegory as well as in the sense of what is in a person from birth (what is innate) as opposed to norreture (what is acquired), as for example in the frequently cited proverb, nature passe norreture (nature over nurture). Restricting the field to just Arthurian literature makes little difference because it represents such a rich and voluminous corpus, which spans three hundred years, from the twelfth to the fifteenth centuries, as well as most of Europe. French Arthurian literature makes up an interesting corpus, both in terms of its scale and the role it played in the diffusion of the tradition.

Nature as a concept has been studied from the perspective of the natural scenery, or countryside, primarily in Romantic literature and American nature writing, which are far removed from the medieval corpuses. It is generally thought that medieval writers showed little interest in the landscape except as literary topoi, which were not very descriptive. This meaning of the word nature is anachronistic in the Middle Ages, because it refers etymologically as well as in Old French to what characterises something from its origins or someone from their birth. The word nature takes on many different values in the Middle Ages - eleven according to Alain de Lille (Solère 2002) - but never the modern meaning of what Zink calls the "belle nature" [beautiful nature] (Zink 2006, 12). Nature in this sense is somewhat ambiguously opposed to norreture (what is acquired) and raises the question of civilisation. This is a theme that receives special treatment in Arthurian literature. One of its overriding concerns is the civilising acts of Arthurian royalty, who establish courtesy and chivalry.

In particular, nature poses the problem of humankind's relationship with the untamed animal and plant world. The pertinence of interpretations based on literary ecocriticism is questionable. While this school is mainly focused on contemporary literature, some studies on texts from the Middle Ages are 
starting to emerge. Most of them, however, are on English literature, particularly Sir Gawain and the Green Knight, while French critiques on medieval French texts remain in the shadows. Nevertheless, it seems possible to re-read some Arthurian episodes in light of ecology. The aim would not be to give perspective to the current ecological challenges by showing them as an atemporal constant of human mentality, however, but to understand through the medieval Arthurian texts, on the one hand, that there is a history of ecological thinking and that humankind's relationship with the environment has a cultural, historic, important and constitutive dimension and, on the other, that it is essential to reconstruct the textual significance of representations of nature without anachronisms. In literary terms, this approach allows us to look at Arthurian texts from a particular angle. This approach does not claim to give a complete view of a text, but it invites us to put into perspective the idea that the Arthurian world is a literary construction, disconnected from the realities of its time and plunged into a bygone era following the death of Arthur; in other words, nothing more than nostalgia. Using traditional approaches that study the representation of nature in texts (studies based on the relationships between nature and culture) and an approach inspired by ecocriticism, we will therefore apply new critical approaches to French Arthurian material.

\section{Scenery and landscapes}

While scenery and wild landscapes have been the subject of study in various literary fields since the emergence of Romanticism and nature writing, they have never been studied in medieval Arthurian literature. Arthurian texts have mainly been a vehicle for topical representations, where the locus amoenus, passed down from antiquity and celebrated by the lyric (Curtius 1956, 317-322), and the locus terribilis, vaguer but just as topical, are pitted against one another (Juan Muela Equerra 2002; Bermejo Larrea 2012; Verelst 1994). On the one hand, there is the welcoming forest, the birds and the reverdie [fresh new greenness] in the opening lines of Le Conte du Graal ${ }^{1}$. The adventure-filled or love-filled orchard (like that of the Joie de la Cour in Erec et Enide 1. 5689-5714), adorned with a spring/fountain and a pine tree, where Tristan and Isolde meet - a scene reproduced on many an ivory casket after the appearance of the romances by Béroul and by Thomas. The spring/fountain, to which the knights make haste to rest after a battle or to weep over the woman they love, particularly in Tristan en Prose ${ }^{2}$. On the other hand, there are places filled with fear. Dense forests full of dangerous adventures and monsters lying in wait. Castles ruled by bad customs. Uneasy seas crossed by Tristan

\footnotetext{
${ }^{1}$ Ce fu au tans qu'arbre florissent, / Fueillent boschaige, pré verdissent, / et cil oisel an lor latin / dolcement chantent au matin, / Et tote riens de joie anflame ["It was the time when the trees were blossoming, the woods were becoming covered in leaves, the meadows were turning green, the birds were singing their songs sweetly in the mornings and everything was flush with happiness" (author's translation, translated into English)].

${ }^{2}$ Cele fontaine estoit aucqes avironnee de granz arbrez qi le lieu fesoient asséz delitable et qi mult l'enbelisoient ["This spring/fountain was almost completely surrounded by tall trees, which made it a very pleasant place and much enhanced" (translated into English)] §4; et trovent adonc la sorse d'une fontaine qi coroit trop clere et trop belle par une arbroie ["and then they fell upon a spring/fountain, which flowed through the trees, quite beautiful and crystal-clear" (translated into English)] §18; Et la fontaine sordoit en .I. tres biax lieu, environné de trop grant planté d'arbres ("and the spring/fountain gushed out in a very beautiful place, surrounded by many trees" (translated into English)] §19.
} 
and the knights of the Holy Grail and islands with sirens, as in Le Conte du Papegau (237), or fairies (like Avalon). Supernatural places, like the Ile d'Aimant (Ferlampin-Acher 88-96) ${ }^{3}$, mountains (where the monsters hide) and lakes (like the Lac de Lausanne, where the monstrous cat of the Suite Vulgate of the Merlin Livre lives). There are the fairies, like the Dame du Lac, and ultimately, there are the rivers, which form the boundaries to the hereafter. The loci terribili borrow from the infernal imagination, and the loci amoeni from Edenic representations. Space is more symbolic than picturesque. The miniatures maintain the vagueness of the evocations, especially in the oldest manuscripts. The pictorial landscape, like the portrait, only undergoes a gradual development prior to the fourteenth century, when literature, including Arthurian literature, rightly begins to accord it some importance, both within the text and in the miniatures.

Although real names are used, the toponymy is often enough to suggest the natural scenery. Take, for example, Broceliande or Gales in Chrétien de Troyes' Le Chevalier au Lion or Escosse, Wincestre and Londres in La Mort le Roi Artu, which contains a substantial mention of the British area as would be expected. Some names seem to be imaginary, however, and difficult to associate with real places. This is either because the copyist has not recognised the names and misrepresented them or because they have become associated with new meanings (while Orcanie refers to the Orkney Islands, the name in this form would have conjured up the disquieting infernal place associated with the classical god Orcus in the minds of cultivated medieval readers). What does Lamborc correspond to in La Mort le roi Artu and Landuc in Erec et Enide? While a name based on reality would enable medieval readers to create a representation of scenery, not all readers had the same cultural backgrounds, and names that were evocative for one reader might not mean anything to another. The modern reader risks being confused by imagining the Broceliande in Chevalier au Lion (v. 187, v. 697) through the lens of its current touristic reality. In the imaginary toponymy, which characterises more than situates places, the picturesque dimension is much reduced. Perilleuse forest [Dangerous forest] and Fontaine aventureuse [Adventurous spring/ fountain] suggest the function of a place to the reader without describing it. Adventure settings are filled with encyclopaedic-type references, which medieval readers were able to understand and picture in their minds (particularly when they were associated with a merveille [marvel]) thanks to knowledge they had acquired from encyclopaedias. Encyclopaedias were fairly widely accessible as they were written in the vernacular from the thirteenth century onwards. Although this was less the case for Arthurian texts than for the material coming out of Rome and the stories about Alexander the Great, it was true for example for Mont Gibel (Etna) in Floriant et Florete (Wolfzettel 2011) and the gouffre de Sathalie [Gulf of Sathalia], where the Laide Semblance lies in Le livre d'Artus (Ferlampin-Acher 2002, 304-310).

\footnotetext{
${ }^{3}$ The Arthurian knight travelled mainly by land, through the forests, but when confronted with the spiritual adventures of the Holy Grail, the space of choice for the trial was generally the sea and the islands, particularly in L'Estoire del Saint Graal (Szkilnik 1991, 22-25).
} 
While the concept of landscape was developing in the pictorial arts and literature during the fourteenth and fifteenth centuries, French Arthurian material was no longer very productive. However, Perceforest, which is preserved in fifteenth-century testimonies, sets up a geography that is realistic on the whole in response to the ideological challenges of fiction (Ferlampin-Acher 1993; FerlampinAcher 2010, 168-224). The author presents some descriptions in which nature gives rise to evocations that escape the topical, such as the descriptions of the tide phenomenon in Zealand ${ }^{4}$, the well-kept forest with trees all aligned (Part one t. I, 139) and the sheep passing peacefully by (Szkilnik 1998). There is no longer any evidence of topos in the descriptions of space. It demands interpretation, as much by the character, for whom it presents an enigma, as by the reader (Heidenreich Findley 2012). Perceforest is a romance situated on the fringes of Arthurian material (it recounts the prehistory of the Arthurian world). It was particularly popular in this Burgundian area, where a new landscape art was emerging (Jan van Eyck). It showed a new sensitivity to nature and the landscape in its evocations of a dewdrop or of the malodorous, misty wetlands. Nature does not give rise to purely aesthetic descriptions however. It is populated (often with monsters, such as Hollant the giant, or savages, like the Greeks of Scotland), and it interacts with the protagonists in such a way that it is not possible to extract tableaus from the text. Furthermore, the details that produce an effect of reality are paradoxically often linked to marvels. The reader can imagine the stench and mists of Hollant's marshes (G. Roussineau 1987, 109-112), not from any direct references but because these are the manifestations associated with a monstrous, malodorous, smoke-emitting giant that lives there. This particularly allusive evocation of the marshes is based on both fantastical elements and the diversion of a topos. A heron, which is completely realistic in this context, plays the role of a romantic messenger, adapting the troubadors' nightingale to the real fauna of the marshes.

\section{What is nature?}

The meaning of nature as a physical world excluding humans and their creations only dates as far back as the seventeenth century in France. People in the Middle Ages would not have used the term nature to refer to the elements discussed above. Words in the sauvage [uncultivated] family correspond best in Old and Middle French to our modern idea of nature. In accordance with what its etymology suggests (sauvage from *salvatica, which comes from silva), the forest plays an important role in the Arthurian corpus as a place of otherness. It is where we find anything that is not human. Animals like stags and lions gather there but also monsters and supernatural figures, like fairies, enchantresses and Perceforest's ladies of the forest. It is also where the classical genii loci and the pagan divinities sought refuge after the spread of Christianity. Comparative approaches concerned with beliefs, folklore and mythology can shed light on this (Ferlampin-Acher 2010; Lecouteux 1995;

\footnotetext{
${ }^{4}$ He mentions the sea, the flat earth, the wetland birds and a hillock, where the shepherds and their flocks would take refuge when the sea level rose (Part three t. III, 59-60). The wild Zealand was regularly subjected to violent tides and storms and submerged under water.
} 
Walter 1988). Marked by an ontological otherness, fairies ${ }^{5}$, luitons [goblins] such as Zéphir in Perceforest, giants and beste glatissant [yelping beast] (Ferlampin-Acher 311-322) rub shoulders in the forest with creatures who are sociologically different, like hideous old women ${ }^{6}$ or Yvain's monstrous Bouvier (1. 276-311) $)^{7}$ and felons, traitors and thieves of all descriptions, who are sometimes marked by the supernatural, like the sons of netons [demons] in Yvain (v. 5263-5331). Confronted with these wild creatures, the heroes antithetically assert themselves as courteous. Many examples of this are presented in the Arthurian corpus. The hero is the civilising element. King Arthur - even from the earliest texts (Historia regum Britaniae) - is the man who conquers the barbarism of the gigantic Riton, and a refined, courteous civilisation grows around him. Also found in this wild place are hermits, like the man who put Perceval back on the right track in Le Conte du Graal (he lives in un desert [a wasteland] v. 6031), and the Cistercians, as in La Queste del Saint Graal. The forest, like all nature created by God, offers the character - and the reader - a set of signs to decode. This notion of integumentum, theological nature also serves as a basis for semiotics, which underpins the interpretation and decoding of the knights' adventures in a quest for meaning other than just the trials (Zink 2006, 36-37). Untamed nature provides the framework both for adventure, whether chivalric (fighting giants, monsters, felons, etc.) or spiritual, and for a chivalry that is both terrestrial and celestial.

However, this place cannot be superimposed onto our own notion of untamed nature, which we imagine as empty of any human mark or presence. On the one hand, it is essential, in order to avoid anachronisms, to base literary approaches on historical knowledge. The relationships between humankind, animals and plants are cultural facts with a historical dimension, which ignorance can lead us to misinterpret ${ }^{8}$. On the other, the untamed nature found in Arthurian romances is not always a deserted place. Emptiness has no meaning for the medieval hero. The forest is peppered with clearings and paths, and it is inhabited. It is where the hero finds the adversaries who are worthy of his heroism and the hermits who guide him. These are not blank spaces in the texts. They are isolated, like the medieval forests, but they are accessible. In reality, the forests were populated areas, where pigs were taken to feed on acorns, where people hunted and where they moved about from one place to another. It was its ambivalence that was interesting and not, like today, the dream of untouched authenticity. The romances show an appreciation for intermediate places, like the orchard, which lie somewhere between wild nature and space tamed by humankind. The idea of a land untouched by human hands

\footnotetext{
${ }^{5}$ The hero in Artus de Bretagne meets the fairy Prosperine [\$249] beneath an oak tree in the moonlight, in a forest edged by a meadow and a path.

${ }^{6}$ The castle of the monstrous old woman, horned aussi comme sauvaige bieste [like a wild beast] in Les Merveilles de Rigomer v. 3510 and v. 3542, lies in the foriest si parfont [forest so deep].

${ }^{7}$ The bouvier was found in an essart (clearing). Deforestation was carried out in the Middle Ages. This realistic space, where savagery and civilisation meet, represents the character's struggle between the human and the animal and between the natural and the supernatural.

${ }^{8}$ The portrayal of the stag as an enchantress's pet in Perceforest might be considered fantastical, but it was not. Does and stags were bred in enclosures in the Middle Ages.
} 
with no discernible trace of human activity is not relevant in the romances. In French, for example, the word fontaine can refer to a natural spring or a man-made fountain. We can see in the miniatures that there is often uncertainty when depicting a scene showing knights at the fontaine between a natural water course and a man-made construction. Neither does the modern bipartition that opposes nature and the town (such as it is represented in the fabliaux) feature in Arthurian romances. The city is only barely present in the form of the court, and it is often not very city-like, opening onto an orchard. Evocations of the towns and the bourgeoisie are rare, particularly in the twelfth and thirteenth centuries, although Gauvain in Le Conte du Graal is attacked by the Escavalon commune, which was an opulent city, described by the author as having resident moneychangers and artisans (v. 5692 $5716)^{9}$. Later romances, however, give an account of the evolution of the bourgeoisie at the end of the Middle Ages as their readership expanded socially. They were more receptive to evocations of the city, like the descriptions of Argençon in Artus de Bretagne (§184).

Our relationship with animals and the supernatural cannot be transposed onto medieval Arthurian texts ${ }^{10}$. The domestic animal is almost entirely absent from the corpus. Husdent is more a hunting dog than a companion, and the horse, while it is often mentioned as a utility animal, does not gain any narrative dimension. The cat that rages by the Lac de Lausanne in the Vulgate Suite du Roman de Merlin before becoming a monster is a petit chaton [little kitten] pulled from the water and adopted by a fisherman, however it would be a mistake to liken this animal to our modern companions. The fisherman took it in so that it would hunt rats and mice, but in transforming it into a monster, the text represents medieval reservations about cats (they often preferred the ferret, and black cats had a rather dark reputation $)^{11}$. This monstrous cat did not represent a deviation from a pet cat; it was a hyperbolic realisation of what a cat represented in the Middle Ages. While the domestic animal is rare, however, the beast takes on a totemic quality and becomes a double of the hero, like Yvain's lion or Arthur's papegau [parrot] in the Conte du Papegau. The animal is often a hostile, evil force like a monster, but it can also be a magical messenger, like the white does, or providential, like the stag in La Queste del Saint Graal. Sometimes it is a sign, a presage, as is the case with Sara's foal in Perceforest (Ferlampin-Acher 2002, 265). There are many episodes, however, that present the porous nature of the boundaries between humans and animals. Only an era that lived in such close proximity with animals (even in close confinement) could be so fascinated by the fragility of what separates humans from animals. This is in spite of the fact that Genesis guarantees the irreducible supremacy of humans over

\footnotetext{
${ }^{9}$ However, the town is given a prominent place in classical romances and romances like Floire et Blancheflor and Galeran de Bretagne.

${ }^{10}$ There are many studies (see bibliography in Fabri-Tehranchi and Russakoff 2014, 215-231). However, the Arthurian corpus in its entirety has not been the subject of any specific studies.

${ }^{11}$ This episode has an aetiological dimension (it "invents" an origin in the name of the Mont du Chat, which overlooks not the Lac de Lausanne but the Lac du Bourget). This cat is immediately fantastical. It is black and can only be unnatural because it likes water (Les Premiers faits du roi Arthur 1606-1609).
} 
animals ${ }^{12}$. In the Arthurian world, humans metamorphose into animals, as in the episode of Caradue in the first Continuation du Conte du Graal (2047-2087) ${ }^{13}$. Even Merlin - who is the son of the devil takes the form of a stag ${ }^{14}$. Metamorphosis into an animal often denotes a sexual issue, such as we find in Caradoc's greyhound bitch, sow and mare, and when Estonné becomes a bear in Perceforest. There is also Liriope's greyhound bitch and her lover's magnificent bull to expiate their amorous impatience at the house of peneance [penitence] (Ferlampin-Acher 268-272) ${ }^{15}$. The werewolf is rare in Arthurian literature however (although it serves as a backdrop in Guillaume de Palerne). At most, Perceforest makes a fleeting allusion to this belief, which was somewhat devalued at the time (Ferlampin-Acher 2011). The porous nature of the boundaries between humans and animals is also found in the representation of hybrids, like the knight-fish in Perceforest. These serve not as foils but as models to humans for the creation of tournaments (Ferlampin-Acher 2002, 299-304). There are very few occurrences of hybrids in Arthurian material however. The motif of hybridisation was most successful at the end of the Middle Ages, after the Arthurian period.

In contrast, the relationship between humans and the plant world receives hardly any attention, even though it appears essential to situate texts in relation to medieval mentalities and practices (Clément 2008). Metamorphoses into plants, which were so popular in the classical texts, are entirely absent from medieval literature, with the exception of Ovidian references. At the most in Arthurian material (and elsewhere), there are some heroines with names that refer to plants, such as Blancheflor, the damsel Perceval is in love with in Le Conte du $\mathrm{Graal}^{16}$. Arthurian flora shows little variation. Artus de Bretagne stands out for the importance he places on the marigold [solsequia] and its solar symbolism (Ferlampin-Acher, 2016). The rose, lily, oak and pine make frequent appearances, and any mentions that deviate from this norm stand out. The cultural context sheds light on these references, albeit the modern reader often lacks the right tools to interpret them. Le conte du Graal opposes charm (v. 6128) (which rhymes with desarme [to disarm], which the hero ties his horse to when he goes to see the hermit) and oak (v. 6312) (which grows in many Arthurian forests and which definitely has a certain warrior dimension [Clément 2008, 107-131]). In particular, the plant world is called on to evoke spring and the call to love and to create within the framework of the reverdie [fresh new greenness]

\footnotetext{
${ }^{12}$ The trend for domestic animals in the modern age shows that humans no longer fear the beast and that they can get close to them emotionally without the fear of any sudden change.

${ }^{13}$ An enchanter, in love with Ysaive who married Caradué, successively makes the damsel appear as a greyhound bitch, a sow and a mare, which the hero mates with. This episode, which perhaps transposes the taboo of zoophilia, has often been commented on (Baumgartner 1984).

${ }^{14}$ The episode of Grisandole in the Vulgate Suite du Merlin (Les premiers faits du roi Arthur 1226-1253) is frequently commented on. In this tale, based on sexual cross-dressing, Merlin takes the form of a savage.

${ }^{15}$ While Eliavrés transforms a greyhound bitch into a woman in the story of Caradoc, the reverse is the case in Perceforest, where the damsel becomes the greyhound bitch. This animal has an ambiguous symbolism, representing both fidelity and lechery.

${ }^{16}$ This name has never attracted any attention. While it is certainly commonplace (it is shared by the heroine in Floire et Blancheflor), is it a coincidence that Perceval, had he asked the right question, would have restored the fertility of the terre gaste [wasteland]? Is it by chance that, after having been a great hunter and devouring the little pastries and discovering a food of penitence (which was probably part plant) from the hermit on his road to redemption, Perceval falls in love with a Blanchefleur?
} 
and female beauty. Notwithstanding the presence of harrowmen at Perceval's mother's service in Le Conte du Graal, agricultural mentions are rare.

Nature, when set in opposition to humans, does not just define itself in relation to the plant and animal world however. For the modern reader, it also defines itself in relation to the supernatural, which disrupts the natural course of things. Caution must be used when applying this notion, however, since it is anachronistic to the Middle Ages. The soothsayers and demons can disrupt the natural course of things, but as creatures of God, they are part of the world order. Nature in its entirety includes not only the everyday but also the merveilles, the astonishing happenings (merveilles belongs to the mirari family [to be astonished]). The supernatural is not in opposition to nature; it is just an unusual form of it. Furthermore, the supernatural is often represented as the hyperbolically natural. The monster - an astonishing merveille - is a superlative animal, often made up of several animals with a higher concentration of animality indicators than a normal animal, and the fairy is a superlative woman (superlative in beauty, maternal qualities [like the Dame du Lac], treachery [like Morgue], and so on).

The idea of nature is not, therefore, simply part of a binary representation that opposes it to civilisation, humans or the supernatural. Rather, it has to do with time and the future, as its etymology suggests (in connection with the idea of birth and creation). The word nature is most often used to refer to what is innate in human beings. Following in the wake of classical representations of the goddess Matura, it most often appears in allegorical form as the ruler presiding over the future of all living beings, including humans. While nowadays we think about nature in terms of its problematic relationship with humankind and seek some sort of reconciliation, in the Middle Ages, nature was within humans as well as all around. It was an allegorical figure that was able to become a real character. It plays an important role in the Roman de la Rose. In Arthurian romances, which are far removed from this allegorical creation, nature is very understated. The exception to this is Perceforest, which revived Arthurian material at the end of the Middle Ages. Perceforest enters into dialogue with the Roman de la Rose and even with Alain de Lille's De planctu naturae, in which Nature is indignant that a virgin can be pregnant (Ferlampin-Acher 2010, 300-340). The Roman de la Rose uses Nature to condemn the seeking of pleasure when it is dissociated from procreation and calls into question the fin'amor [courtly love] and thus, indirectly, Arthurian love (even though the romances, more so than the lyrics, ended in marriage). In contrast, Perceforest reconciles Nature and the Arthurian romance with no hint of prudishness, particularly through the luiton [goblin] Zéphir, who, as the guardian spirit of the Scottish lineage, is in favour of procreation and allows all Arthurian ancestors and heroes to be conceived $^{17}$.

\footnotetext{
${ }^{17}$ On nature and culture in Perceforest, see Huot 2007, particularly Part I on the primitive people of Scotland.
} 
Aside from this particular case, the nature allegory is especially present in short ornamental mentions, such as portraits ${ }^{18}$. A number of proverbial utterances also depict nature, where the qualities of an individual from birth are referred to (nature in French belongs to the same family as naitre [to be born] and should therefore be seen as connected to the modern inné [innate], which did not enter the French language until the Renaissance as the form enné). These qualities are more important than anything education can provide because in the Middle Ages they believed Nature passe Norreture (nature over nurture) ${ }^{19}$. This saying is especially frequent in romances that socially disorientate their heroes, as in Guillaume d'Angleterre, L'Escoufle and Guillaume de Palerne. Although the Arthurian hero can be humiliated by defeat, he is rarely transplanted into another social environment, hence the relative rarity of this proverb in our corpus. There are exceptions to this however. There is the young Perceval, who was born into a good family but brought up a boor, but proves to be a highly valued knight by the end in Le Conte du Graal. There is also Guillaume le Clerc's Fergus, which parodies Chrétien's work and presents an ambiguous character, the son of a vilain [villein] and a noble lady. He inherits his mother's value - it was assumed that the milk transmitted the maternal qualities to the child. Gauvain's natural sons (Guinglain in Renaut's Bel Inconnu and Lionaus, the son of the damsel of Lis in the Première Continuation of Le Conte du Graal) also illustrate this primacy of nature. The fact remains, however, that the Arthurian domain, in its glorification of nobility and only marginal attention to the education of its heroes (think of the training that the Dame du Lac organised for her protégé, however, in Lancelot en prose), is not particularly interested in the relationship between nature and norreture. Keu, whose mother had breastfed the future King Arthur but who was himself breastfed by a woman of inferior rank, sees his nature corrupted. He is desnaturé [unnatural], but while the texts regularly denounce his sharp tongue, they pay hardly any attention to this trait. Finally then, the appearances of Nature as an allegory and of the term nature in the sense of 'what comes from birth' are marginal and fairly meaningless in the Arthurian corpus in relation to those found in other medieval texts.

However, the medieval conceptions of nature at the intersection of Christianity and contributions from classical philosophers are more enlightening (Solère 2002). Nature in the Middle Ages encompasses the whole of Creation, including humankind. Nature is an entity that towers above everything. The lines between nature and God can be blurred, but most often, nature is submissive to God as the principal Creator. Hence the frequent references to a Nature that forms and shapes and which, as such, can become an auctorial representation. When Nature gives its beauty to a heroine or pushes a character to act in a certain way, it is the author's mask. Moreover, the romance as a literary genre emerged in the French language at the same time as twelfth-century Renaissance with its

\footnotetext{
${ }^{18}$ For example at the château de la Merveille in Le Conte du Graal, Gauvain admires a pucelle [virgin], whose cheeks have been coloured rosy red by nature (v. 7651). This detail is found in many texts.

${ }^{19}$ Morawski 1925. A number of proverbs balance nature and norreture. Most come down in favour of the primacy of nature: Meulz vaut nature que nurreture (Morawski 1925, $\left.\mathrm{n}^{\circ} 1273\right)$, Nature ne puet mentir $\left(\mathrm{n}^{\circ} 1327\right)$, Nature passe norreture $\left(\mathrm{n}^{\circ}\right.$ 1328), and Plus trait nature que cent beufs ( $\left.{ }^{\circ} 1655\right)$.
} 
Neoplatonism, which renewed the literary relationship with Nature (Ribémont 2002). The hero (like the poet) was therefore in direct contact with the whole of Creation, which he was given to become acquainted with. Erec's coronation robe, into which was figurally woven all the knowledge in the universe, represents the profound link between the hero and the world (v. 6672-6748; Hart 1981). In the thirteenth century, the resurgence of Aristotelianism prompted a revival of interest in nature and all its manifestations, boosting the distribution of encyclopaedias, including those in the vernacular. Around 1300, in Artus de Bretagne, Estienne, knight and scholar, seduced Marguerite by giving an encyclopaedic talk on the world, the planets and meteorology (\$217 and §218). The Arthurian romance was able to represent scholarly knowledge on nature, admittedly with the additional challenge of popularising it, but also and especially with the aim of glorifying the scholar and, through him, the poet, who was the hero knight's rival. With Merlin (and Blaise, see Berthelot 1991) and Estienne in Artus de Bretagne (Ferlampin-Acher 1994 and 1995), the Arthurian romance writer invents doubles, demonstrating his knowledge of the world and the natural world in particular.

The questions posed by nature, whether considered in terms of its modern meaning or its medieval values, are therefore diverse, and they reveal anthropological just as much as poetic problems. Long before the advent of nature writing, Arthurian texts conferred a prominent place to humankind both in the story and in the world, but always under the guardianship of God, a creature among all the others.

\section{Ecocritical approaches?}

There are still very few studies on Arthurian texts using ecocritical approaches. Contemporary literature has been largely preferred as an object of study because of current ecological issues. However, even though the contemporary crisis is unprecedented, it presents us with a useful tool for thinking about humankind's place in nature and for shedding light on the archaeology of its representations. Putting the idea of human exceptionalism to the test can be fed by medieval representations, which establish a continuum between human beings and animals. This continuum is deeply rooted in the imagination (as is revealed in the metamorphoses and the emergence of totemism) and relayed by Christianity because even though Christianity establishes a barrier between humankind and the animals in Genesis, it makes them both God's creatures (did we not see this in Francis of Assisi, the first ecologist?) Moreover, the Middle Ages had its own problems with pollution and climatic disturbances. It may be that the Arthurian texts contain more traces of these than other genres inasmuch the founding themes are the terre [land] rendered gaste [wasteland] by human failings and the supernatural storms caused by a human action (for example, at Brocéliande). While the English (Rudd 2014) and even the German (Classen 2015) corpuses have given rise to ecocritical approaches, these have often taken the form of thematic studies, dealing, for example, with trees, the sea, and so on (Rudd 2007), and they have focused on only a few texts (Sir Gawain and the Green Knight in 
particular) or subjects (such as the forest) ${ }^{20}$. As far as the French corpus is concerned, there are some studies underway, but these have mainly been done in Britain and the United States. The ecocritical approach has only been marginally taken up in French criticism within the context of classical and particularly medieval literature.

However, there are a number of elements that encourage us to think of medieval literature, and Arthurian literature in particular, as a pertinent field for ecocriticism, provided vigilance is always maintained regarding the meanings of words in the Middle Ages (nature, as we have seen, is problematic ${ }^{21}$ ) and the risk of anachronisms. People in medieval times, as in classical times, were always aware of natural calamities and considered them to be disturbances. The majority of medieval encyclopaedias, particularly those that circulated from the thirteenth century onwards, mention cataclysmic events, like earthquakes, storms, and so on. In this period of rediscovering Aristotelianism, they were the object of scientific knowledge, as they are today. Nevertheless, the explanations given for these disturbances are human failings. While the causality is not scientific and while it is important, for example, not to consider human responsibility in today's global warming on the same level as the idea that a storm at sea is the consequence, dished out by Providence, of the bad behaviour of a traveller, the idea that human fault is involved is nevertheless still present almost a thousand years on. This idea of fault is nowadays often superimposed on that of responsibility, even if it has to be greatly distorted (Jouanna, Leclant and Zink 2006). The impact of human beings on nature, particularly as a result of work since the Fall, is thought of as a fault. From the work of Chrétien de Troyes and Robert de Boron onwards, the graal [grail] is linked to a terre gaste [wasteland] and is replicated by the attack suffered by the mehaigné [injured] king and associated with a succession of failings, particularly Perceval's. Perceval does not know how to ask the right questions, and before he learns moderation, particularly from the hermit in relation to food, he unrestrainedly devours the little pastries made by the damsel in the tent. The motif of the Holy Grail, posing the question of food, exhaustion of the land and human sickness, suggests a reflection on abundance and penury and one element of this is the opulence of the service of the Holy Grail. Food scarcity was a worrying prospect

\footnotetext{
${ }^{20}$ This is the only subject called upon by English Arthurian literature in Aberth 2013. The forest is effectively an essential space in the medieval tale, Arthurian or otherwise (Saunders 1993). It is also worth noting the collection of essays on medieval Spanish literature, which is organised around a Nature Untamed, Nature tamed, Nature Stylized opposition (Scarborough 2013).

${ }^{21}$ Moreover, the word environnement is a Middle French creation and more recent than avironnement (on environ, that which surrounds). It had a spatial value and referred to a circuit, a contour, the margins of a page or the act of surrounding and its result. It was only through a semantic borrowing from the English environment at the beginning of the twentieth century that it took on the meaning of the set of physical elements and phenomena that surround a living organism. Around 1960, its use extended to the domains of ethology and ecology ("the set of natural and cultural conditions likely to have an effect on an organism" [Rey 2006, 1261]). However, we do find evidence of this term in Artus de Bretagne (around 1300, §150, 33) in the Tour Ténébreuse episode, where the initial meaning refers to the mill's grindstones, which surround the Tour with a strong sense of circularity. The episode represents the anxiety surrounding the relatively recent introduction of windmills into Britain, which are characterised by a worrying mechanisation. The hero, the human, is excluded from entering this tower. He has lost his role at the centre of the world, overtaken by the machine, which has also disrupted the rhythm of the seasons (Ferlampin-Acher 2013). In this decentring against nature in medieval thinking, the people perceive themselves to be already thrown aside by early industrialisation. Environnement refers both to the anthropocentrism of representations (humans want to be at the centre) and to the threat of decentring, where the machine takes the upper hand.
} 
for medieval man, and it raised the issue of the bad management of nature and humankind's responsibility, seen from the perspective of fault.

More so than any other body of medieval texts, therefore, Arthurian material poses the pressing problem of the uncertain relationships between human beings, the human body, the earth that feeds it and God. Rash acts by knights lead to disasters. While Yvain's bouvier, for example, knows what to expect from the spring/fountain and guards the herd, careful not to cause any disturbances (Zink 2006, 188 and 193), first Calogrenant and then Yvain disrupt the natural order and trigger a storm. Yvain then has to pass through the madness in the forest for order to be restored. The hermit in Le Conte du Graal returns Perceval to both the liturgical and seasonal rhythms. Perceval's excessiveness seems to be particularly denounced in Fergus. The romance can of course be interpreted as a simple parodic game, but it also seems to oppose Fergus and Perceval. Ultimately the true hero, Fergus is the son of a vilain [villain], who is close to the primitive world and far removed from the world of the court. $\mathrm{He}$ is Perceval's double (Ferlampin-Acher 2015), who goes on to make him a knight, thus marking the transition from one generation to the next. In Fergus, the meeting between the eponymous character and the court is preceded by an episode in which Perceval hunts down and violently kills a stag (the text emphasises the cries of the beast, the blood and the agony v. 200-232). There are very few texts in which the hunt is presented with such brutality. In Arthurian tales, the hero generally follows the game, which leads him into an adventure, but he does not actually slaughter it. Perceval is discredited, much more so than the uncouth Fergus.

Moreover, the British material, as already reported by Jean Bodel, is differentiated from the materials of France and Rome by its amusing merveilles vaines [pointless marvels]. These merveilles are at the intersection of the natural and supernatural. They are astonishing, and they move away from what the character is expecting and invite him (and the reader) to understand. The enchanters, like Merlin, and the fairies regularly disrupt the expected order of things. They personify the Promethean temptation of humans to transform the world and the fear that this arouses. The supernatural constitutes a paradigm of the approach to ecological phenomena when they are in a state of crisis. The Arthurian world is centred around Arthur - whose conception disturbs the natural order of things and who never really dies - and the civilising actions of a knight who conquers the world but ultimately disappears. Perhaps this medieval world is marked by a relationship with nature that is comparable to the one that activates ecological sentiment. The great king is condemned to die and his world to be wiped out because both are characterised by a flawed relationship with nature.

The context must also be taken into consideration. The Little Ice Age and the Black Death caused an ecological disaster from the thirteenth century onwards (Bowlus 1980; Aberth 2013), but Arthurian 
literature gives scant account of these events because it was largely written prior to their onset ${ }^{22}$. Later, however, the numerous storms in Perceforest and the frequent dark clouds triggered by Estienne in Artus de Bretagne (Ferlampin-Acher 1995 and 2008), while they correspond to the powers of the stormcallers widely attested throughout the Middle Ages, also perhaps owe a lot to the new meteorological conditions.

A parallel must also be drawn between Arthurian literature and the major transformation that Jean Gimpel considered to be an industrial revolution (Gimpel 1975). In the twelfth and thirteenth centuries, Europe (particularly France, the Burgundian territories and England) experienced the start of industrialisation and, with it, an expansion of the cities and towns that prefigured the Industrial Revolution of the nineteenth century. Just as the trial of Pesme Aventure in Yvain - which saw the hero battling against the supernatural sons of a netun [demon] - represents the sad historic status of silk workers in the Middle Ages (Cassagnes-Brouquet 2013), so a number of equally fantastical adventures show, using hyperbolic transposition, that there was already concern over the perverse effects of human activity and pollution (Leguay 1999). Nigremance [necromancy], which enabled enchanters to disrupt the order of things, was becoming increasingly demonised at the end of the Middle Ages. In Artus and Perceforest, it triggered foul-smelling, black clouds. Ever since the Douloureuse Garde episode in Lancelot en prose, people had been reluctant, frightened even, when it came to mechanisation with its machines, arbalests and clocks (Ferlampin-Acher 2012, 2015a, 2015b; Zink 2006, 133). While towns and cities were polluted in real life, none of this was apparent in the fictional cities, but it was perhaps to them that the worrying fantastical places owed their foulsmelling, black rivers (such as at the Porte Noire and the Tour Ténébreuse in Artus de Bretagne). In Perceforest, the homes of the damsels of the forest draw together representations inspired by contemporary human industry. Lime kilns were a cause of pollution often condemned in the Middle Ages (Gimpel 85). In Perceforest, the home of Sibille, an enchantress, disappears from view while the nearby lime kilns stand, quite an uncommon sight in Arthurian forests ${ }^{23}$.

Likewise, the mining industry (particularly tin) was developing throughout the Middle Ages in England (Gimpel 33-48). Again, this reality is represented through an enchantress in Perceforest, since the damsel in the Chastel d'Estain is connected with the mines near Cornwall, which had been

\footnotetext{
${ }^{22}$ It should be noted, however, that the modern reader must bear in mind that the climate prior to 1300 was milder than it is today. This makes the snow exceptional in the Conte du Graal and invites us to reconsider the episode of the drops of blood on the snow as a climatic merveille.

${ }^{23}$ Part one $\$ 216$. The beginning of the episode mentions Alexandre and Floridas' ride in the forest, which is relevant (il ne leur souvenoit fors que de regarder la noblesse des arbes et de oür le chant des oyseaulx). The next element is more surprising, however. They smell une moult grant fumee, which lures them, and then ilz troeuvent ung chault four la ou on faisoit chaux. They question the workers, who tell them about the home of Sibille, which was made invisible by magic. In $\$ 217$, a worker explains that he regularly delivers lime to the fairy, who is, like Mélusine, a builder fairy. The juxtaposition in the tale of the smoke from the lime kiln and the invisibility of the castle suggests to the reader a cause and effect relationship, which comes to superimpose itself on the supernatural hypothesis. In Book IV, the lime kiln is used to describe the horrible smoke coming from Hollant the giant, which is so puante [foul-smelling] that the birds who breathe it in die (et sambloit de la fumee qui partoit de lui que ce fust ung chauffour [Part four 111]).
} 
exploited since the time of the Trojans (\$1134). Artus de Bretagne invents two supernatural places, the Porte Noire and the Tour Ténébreuse (a kind of fantastical, hyperbolic mill), which represent the dismay caused by the fairly late introduction of windmills into Britain (Ferlampin-Acher 2013).

At the end of the Middle Ages, the romance's tendency to become rooted in a place, albeit a fantastical one, that presents indices of reality combined with the effects of progressive industrialisation and the political (the Hundred Years' War), spiritual (demonization of the imagination), climatic (the Little Ice Age) and sanitary (the Black Death) crises foster the presence of elements in the Arthurian romances that can be given an ecological interpretation. Paradoxically, these indices enter into the text in connection with the merveille (fairies, monsters, etc.) in particular. On the one hand, the concerns of everyday life can only be of interest to literature if enhanced by the extraordinary. On the other, the supernatural is particularly apt for rendering what was perceived, from this era onwards, to be bringing trouble.

It is true that Arthurian texts paint very few landscapes in the modern sense of the term, although they do appear in the later texts. Nevertheless, we have to put into perspective the intuitions that tell us that Arthurian literature, which puts knights to the test in the forest, opposes nature and civilisation as modern mentalities, and that this literature, which came a long time before the Industrial Revolution, cannot represent ecological issues. While the number of studies on the representations of nature and the relationships between humans and animals are growing, the more ecological approach appears promising, particularly for the later texts. This may lead to a revision of the idealised image in Arthurian texts of a medieval world that resembled Eden. 


\section{Primary sources}

Artus de Bretagne. Ed. Christine Ferlampin-Acher. Paris : Champion, 2016.

Béroul, Tristan et Iseut. Ed. Daniel Lacroix et Philippe Walter. Paris : Le Livre de Poche, 1989.

Chrétien de Troyes. Erec et Enide. Ed. Mario Roques. Paris : Champion, 1989.

Chrétien de Troyes. Le chevalier au lion (Yvain). Ed. Mario Roques. Paris : Champion, 1982.

Chrétien de Troyes. Le Conte du Graal. Ed. Félix Lecoy. Paris : Champion, 1973.

Conte du Papagaut. Ed. Hélène Charpentier and Patricia Victorin. Paris : Champion, 2004.

Estoire del Saint Graal. Ed. Jean-Paul Ponceau. Paris : Champion, 1997.

Guillaume le Clerc. The Romance of Fergus. Ed. Wilson Frescoln. Philadelphia: Allen, 1983.

Merveilles de Rigomer. Ed. Wendelin Förster. Dresden: Gesellschaft für romanische Literatur; Halle: Niemeyer, 1915.

Mort le Roi Artu. Ed. David F. Hult. Paris : Librairie générale française, 2009.

Perceforest. Ed. G. Roussineau. Genève : Droz. 1982-2014 (première partie t. I et II, 2007 ; troisième partie, t. III, 1993, quatrième partie t. I, 1987).

Premiere continuation de Perceval. Ed. W. Roach. Paris : Librairie générale française, 1993.

Proverbes français antérieurs au XV s.. Ed. Joseph Morawski. Paris : Champion, 1925.

Queste del Saint Graal. Ed. Fanni Bogdanow. Paris : Librairie générale française, 2006.

Tristan en prose. dir. Philippe Ménard. Paris : Champion, 1997-2007 ; t. V, Christine FerlampinAcher, 2007.

\section{Secondary sources}

Aberth, John. An environmental history of the Middle Ages. The crucible of Nature. Londres et New York : Routledge, 2013. 
Baumgartner, Emmanuèle. "Caradoc ou de la séduction". Mélanges de langue et de littérature médiévales offerts à Alice Planche. Ed. Ambroise Queffélec et Maurice Accarie. Paris : Les Belles Lettres, 1984. t. 1, 61-69.

Bermejo Larrea, Esperanza. Regards sur le locus horribilis. Manifestations littéraires des espaces hostiles. Zaragoza : Prensas de la Universidad de Zaragoza, 2012.

Berthelot, Anne. Figures et fonction de l'écrivain au XIIIe siècle. Montréal: Institut d'Etudes Médiévales ; Paris : Vrin, 1991.

Cassagnes-Brouquet, Sophie. "La Pire des Aventures : le chevalier Yvain et les tisseuses de soie", Clio. Femmes, Genre, Histoire, 38 (2013) : 235-240.

Classen, Albrecht. The Forest in Medieval German Literature: Ecocritical Readings from a Historical Perspective. Lexington: Lexington Books, 2015.

Clément, Myriam. «Contes d'arbres, d'herbes et d'épée : approches du végétal dans le roman arthurien des XIIe et XIIIe siècles », doctorat, University Rennes 2. 2008.

Curtius, Ernst R. La littérature européenne et le Moyen Âge latin. Paris : Presses Universitaires de France, 1956.

Fabry-Tehranchi, Irène and Russakof, Anne (ed.), L'Humain et l'Animal dans la France médiévale (XIIe-XVe s.). Amsterdam New York: Rodopi, 2014.

Ferlampin-Acher, Christine. "La géographie et les progrès de la civilisation dans Perceforest". Provinces, régions, terroirs au Moyen Age, de la réalité à l'imaginaire. Ed. Bernard Guidot. Nancy: Presses Universitaires de Nancy, 1993. 275-290.

Ferlampin-Acher, Christine. "Epreuves, pièges et plaies dans Artus de Bretagne: le sourire du clerc et la violence du chevalier ”. La violence au Moyen Age, Senefiance 36 (1994) : 201-218.

Ferlampin-Acher, Christine. "Grandeur et décadence du clerc Estienne dans Artus de Bretagne". Le clerc au Moyen Age, Senefiance 37 (1995) : 167-195.

Ferlampin-Acher, Christine. Fées, bestes et luitons. Croyances et merveilles dans les romans français en prose (XIII -XIV siècles). Paris : Presses Universitaires de Paris Sorbonne, 2002.

Ferlampin-Acher, Christine. "Voyager avec le diable Zéphir dans le Roman de Perceforest (XVe siècle) : la tempête, la Mesnie Hellequin, la translatio imperii et le souffle de l'inspiration". Voyager avec le diable: voyages réels, voyages imaginaires et discours démonologiques (15e-17e s.). Ed. 
Thibaut Maus de Rolley and Grégoire Holtz. Paris : Presses Universitaires Paris Sorbonne, 2008. 4559 .

Ferlampin-Acher, Christine. Perceforest et Zéphir. Propositions autour d'un récit arthurien bourguignon. Genève : Droz, 2010.

Ferlampin-Acher, Christine. "Les métamorphoses du versipelles romanesque (Guillaume de Palerne, Guillaume d'Angleterre, Perceforest)". Littérature et folklore dans le récit médiéval. Ed. Emese Egedi-Kovacz. Budapest : Collège Eötvös Jozsef, 2011.119-134.

Ferlampin-Acher, Christine. "Artus de Bretagne aux XIVe et XVe siècles : du rythme solaire à l'horloge faee, le temps des clercs et celui des chevaliers". Cloches et horloges dans les textes médiévaux. Ed. Fabienne Pomel. Rennes : Presses Universitaires de Rennes, 2012. 221-240.

Ferlampin-Acher, Christine. "Le locus horribilis dans Artus de Bretagne (XIVe s.) : de l'Enfer au moulin, le renouvellement d'un topos ». Le locus terribilis : topique et expérience de l'horrible". Ed. Juan Muela Equerra. Bern : Peter Lang, 2013. 49-72.

Ferlampin-Acher, Christine a. "Dédale et Icare du XIIe au XVe siècle : artifice et arts mécaniques au Moyen Âge". L'artifice dans les lettres et les arts. Ed. Timothée Picard and Elisabeth Lavezzi. Rennes : Presses Universitaires de Rennes, 2015. 273-284.

Ferlampin-Acher, Christine b "L'arbalète de Passelion dans Perceforest: l'objet, entre tension idéologique et jeu". Engins et machines. L'imaginaire mécanique dans les textes médiévaux. Ed. Fabienne Pomel. Rennes : Presses Universitaires de Rennes, 2015. 66-86.

Ferlampin-Acher, Christine. "La couronne et le chapel de soucis dans Artus de Bretagne". L'œuvre et ses miniatures. Les objets autoréflexifs dans la littérature européenne. Ed. Luc Fraisse and Eric Wessler. Paris : Garnier, 2016.

Gimpel, Jean. La révolution industrielle du Moyen Âge. Paris : Editions du Seuil, 1975 (The Medieval Machine : the industrial Revolution of the Middle Ages. London: Penguin Books, 1976).

Hart, T. Elwood. "Chrestien, Macrobius, and Chartrean science: the allegorical robe as symbol of textual design in the Old French Erec". Mediaeval Studies 43 (1981): 250-296.

Heidenreich Findley, Brooke. “Interpréter le paysage du Perceforest: forêts, jardins, monuments”, Perceforest: un roman arthurien et sa réception. Ed. Christine Ferlampin-Acher, Rennes : Presses universitaires de Rennes, 2012. 203-211. 
Huot, Sylvia. Postcolonial Fictions in the "Roman de Perceforest": Cultural Identities and Hybridities. Cambridge : Brewer, 2007.

Jouanna, Jacques, Leclant Jean and Zink Michel (ed.), L'homme face aux calamités naturelles dans l'Antiquité et au Moyen Âge. Paris : De Boccard, 2006.

Lecouteux, Claude. Démons et génies du terroir au Moyen Âge. Paris : Imago. 1995

Leguay, Jean-Pierre. La pollution au Moyen Âge. Paris : Gisserot, 1999.

Rey, Alain (ed.), Dictionnaire historique de la langue française. Paris : Le Robert, 2006.

Ribémont, Bernard. La Renaissance du XIIe siècle et l'encyclopédisme. Paris : Honoré Champion, 2002.

Rudd, Gillian. Ecocritical readings of late medieval English literature. Manchester: Manchester University Press, 2007.

Rudd, Gillian, "Being Green in Late Medieval English Literature", The Oxford Handbook of Ecocriticism. Ed. Greg Garrard. Oxford : University Press, 2014. 27-39.

Saunders, Corinne. The forest of medieval romance: Avernus, Broceliande, Arden. Woodbridge: DS Brewer, 1993.

Scarborough, Connie (ed.). Inscribing the Environment. Ecocritical Approaches to Medieval Spanish Literature. Berlin Boston: De Gruyter. 2013.

Solère, Jean-Luc. "Nature". Dictionnaire du Moyen Âge. Ed Claude Gauvard and Michel Zink. Paris: PUF, 2002. 967-976.

Szkilnik, Michelle. L'archipel du Graal. Étude de l'"Estoire del Saint Graal". Genève : Droz, 1991.

Szkilnik, Michelle. "Des blancs moutons pasturans les rais du soleil: le paysage dans les marges du Roman de Perceforest", Les Cahiers du S.E.L., Paysage/Paysages, (Séminaire Espace Littérature du Département de Lettres Modernes, Université de Nantes), Nantes, 1998, 1-54.

Verelst, Philippe. "Le locus horribilis. Ebauche d'une étude". La chanson de geste : écriture, intertextualité, translations. Paris : Université Paris X Nanterre, 1994. 41-57.

Walter, Philippe. Canicule, essai de mythologie sur Yvain de Chrétien de Troyes. Paris : SEDES, 1988. 
Wolfzettel, Friedrich. "L’Etna dans la littérature médiévale". Dictionnaire des lieux et pays mythiques. Ed. Olivier Battistini, Jean-Dominique Poli, Pierre Ronzeaud and Jean-Jacques Vincensini. Paris : Robert Laffont, 2011. 466-467.

Zink, Michel. Nature et poésie au Moyen Âge. Paris : Fayard, 2006. 